\title{
Effect of a High Silver Stress on the Element Transfers from a Smectite-Type Clay Substrate to Plants
}

\author{
Khadija Semhi $^{1,2}$, Norbert Clauer ${ }^{1 *}$, Sam Chaudhuri ${ }^{3}$, René Boutin ${ }^{1}$, Mohamed Hassan $^{2}$ \\ ${ }^{1}$ Laboratoire d'Hydrologie et de Géochimie de Strasbourg (CNRS-UdS), Strasbourg, France \\ ${ }^{2}$ Sultan Qaboos University, Muscat, Oman \\ ${ }^{3}$ Department of Geology, Kansas State University, Manhattan, USA \\ Email: ${ }^{*}$ nclauer@unistra.fr
}

Received February 6, 2012; revised March 21, 2012; accepted March 25, 2012

\begin{abstract}
Two species of radishes, Raphanus sativus and Raphanus raphanistrum, were grown in the laboratory in the same substrate consisting of a smectite-type clay, which was watered at the beginning of the experience with $50 \mathrm{ml}$ of a solution containing either none or 1000,2000 or $4000 \mathrm{mg} / \mathrm{L}$ of $\mathrm{AgNO}_{3}$, respectively. Occurrence of the toxic metal in the substrate outlines higher element uptakes by the cultivated species Raphanus sativus than by the wild species Raphanus raphanistrum, except for the highest degree of Ag pollution. After a one-month growth in the Ag-polluted substrate, Raphanus sativus was depleted in most of the major, trace and rare-earth elements, except for $\mathrm{Al}, \mathrm{Fe}, \mathrm{Th}, \mathrm{Ag}$ and $\mathrm{U}$ that increased in the radishes from substrate polluted by $2000 \mathrm{mg} / \mathrm{L}$ of $\mathrm{AgNO}_{3}$, and $\mathrm{Sr}, \mathrm{Co}, \mathrm{Ni}, \mathrm{U}$ and $\mathrm{Ag}$ that increased in the radishes from substrate polluted by $4000 \mathrm{mg} / \mathrm{L}$ of $\mathrm{AgNO}_{3}$. Raphanus raphanistrum was enriched in all elements except $\mathrm{Si}, \mathrm{Na}, \mathrm{Rb}$ and $\mathrm{K}$ in the polluted substrate. The uptake was monitored by a cation-exchange process in the rhyzosphere between mineral particles and the watering solution in the presence of various enzymes with specific activities that induced a variable uptake with the REEs being even fractionated. These activities most probably depend on combined factors, such as the plant species, and the chemical and physical properties of the substrate. The results obtained here reveal also that accumulation of nutrient elements and others in the plants is not uniform at a given $\mathrm{Ag}$ pollution of the substrate and therefore at a given $\mathrm{Ag}$ contamination in the same plant species.
\end{abstract}

Keywords: Ag Pollution; Plant-Growth Experiment; Smectite-Type Clay Substrate; Soil-Plant Element Transfers; REE Fractionation

\section{Introduction}

The main anthropogenic source of heavy metals is presently in the metallurgic activities that often produce punctual elevated concentrations relative to the natural background [1]. Not removable by natural processes, heavy metals persist in the environment for unlimited periods of time with a tendency to accumulate. Heavymetal accumulation raises important questions about their potential impact on the soil mineral and organic components, as well as on their uptake by plants that are grown on metal-polluted soils and are potentially consumed by humans. They exert toxic effects in soils by contributing to biochemical reactions with the organisms, the typical responses being growth inhibition, suppression of oxygen consumption and impairments of the reproduction cycle. Many laboratory studies have been published in the recent decades to determine the response of microorganisms to contaminants released into soils by human activity, e.g., [2-4]. Many of these studies were

"Corresponding author. focused on the inhibitory effect including the reduction of the number, amount and activity of the microorganims, e.g., $[5,6]$, as well as on the significant reduction of the microbial activity, its diversity and structure [7-12].

Toxic ions present in soils can affect plants by damaging their root cells, which may lead to an inhibition in the nutrient transport from soil to root cells. A first-order consequence of such modifications is the reduction of the biomass that may also modify the production of either oxidizing or reducing agents, which, in turn, influences also the transfer of nutrients from soils to plants. Among the most studied heavy metals that damage soils are $\mathrm{Pb}$, $\mathrm{Cd}$ and $\mathrm{Ag}$. Anthropogenic sources of $\mathrm{Ag}$, which impact on plants will be studied here, include $\mathrm{Cu}, \mathrm{Zn}, \mathrm{Sn}$ and $\mathrm{Pb}$ smelters, sewage sludges. It contributes also heavily to toxic waste of the photographic and imaging industry, and of electronic and electrical applications [13]. Silver toxicity has been often determined in aqueous phases; it depends on the concentration of the free active $\mathrm{Ag}^{+}$ions [14] that result from mining activity, e.g., [15-17] or from 
city pollutions [18]. Silver ions are well known for their toxicity with respect to $\mathrm{CO}_{2}$ respiration of microbes in soils: $\mathrm{Ag}$ is considered the most toxic metal among twelve metal sulfides with respect to $\mathrm{CO}_{2}$ respiration in soils $[19,20]$. Silver sulfate also reduces the microbial biomass and decreases the denitrification and dehydrogenase activity in soils $[21,22]$. According to Brooks et al. [23] and Andrew et al. [24], an Ag hyper accumulation is defined at $0.1 \mathrm{wt} \%$ dry matter for most plants.

Despite extensive studies on element uptake and transport in plants, little attention has been paid to their fractionation in bioaccumulation processes. The available interpretations are also often based on investigations of plant-soil systems under open-field conditions. Even if the results of such studies provide useful information, the reactions between soils, microorganisms and plants are at times difficult to decrypt because of the complex composition and structure of the soils that do not allow unequivocal interpretations of the interactions, therefore not being comparable straight to results obtained under other open-field conditions in other soils, and/or under other climates.

In a recent study, the element uptake by spinach was quantified during a three-month growth in an illite substrate under strictly controlled laboratory conditions [25]. The initial taken up of the elements occurred by ion exchange and particle-surface modifications, with a major change in the process after one month of growth, as a new process, namely ion complexation by interaction with organics released by the plant roots, was identified. As this process appeared to have been limited to the particles directly in contact with root exudates, a way of continuing this type of experiment was to focus on the effects of an abnormally high Ag "stress" on the initial uptake potential of two different species of plants grown in an identical, well-known mono-mineralic substrate. The purpose of studying the high Ag contamination was therefore not on potential applications with environmental relevance or on an evaluation of possible toxic effects of the studied vegetables for human consumption.

By carrying out an experiment on element transfers from a variably polluted, well-identified and homogeneous substrate under controlled laboratory conditions, the assigned goal of the present study is the control of the impact of the soil mineralogy on the mass transfers. The choice of pure smectite clay without specific contents of microorganisms as substrate, instead of a generic soil, was dictated by its high capacity of ion exchange with its immediate environment. The purpose was deliberately to avoid the impact of variations in water supply, soil texture, $\mathrm{pH}$, temperature, humidity and availability on the transfer of essential nutrients to plants growing in highly polluted substrates.

In summary, the aim of this study is an identification of how plants take up chemical elements released by the mono-mineral substrate in a situation of extreme metal pollution, by focusing strictly on mineral-to-plant elemental transfers. We had not in mind to make an evaluation of the environmental relevance of the experiment as the type of substrate and the amount of Ag contamination were chosen to be far from natural conditions. Ultimately, the study was also not designed and performed to address biological and metabolic aspects of plants growing on natural soils in outdoor conditions, but to provide some understanding on how two different species of plants select the nutrient and other elements from an extremely Ag-contaminated mono-mineralic substrate.

\section{Description of the Material and the Analytical Procedure}

Two species of radish were selected for the experiment: the cultivated species Raphanus sativus (called $R$. sativus hereafter) and the wild species Raphanus raphanistrum (called $R$. raphanistrum hereafter). The Raphanus gender was selected because it is a fast growing plant, allowing a rapid turnover in the experiment, and the choice of a wild and a cultivated species was decided to identify possible differences in their behavior relative to Ag contamination. The substrate consists of a sedimentary smectite-type clay mineral that is known for its specific high capacity of exchanging elements, such as $\mathrm{Na}, \mathrm{Ca}$ or $\mathrm{Mg}$ and $\mathrm{H}_{2} \mathrm{O}$ molecules, temporarily bond in an interlayer position [26], but also for its lack in soil-type microorganisms. An additional interest for the use of a smectite as a substrate is that its potential in elemental exchange does not alter its crystallographic and constitutive chemical composition, as only the elements hosted by the mineral interlayers are available for ion-exchange. About 700 grams of smectite were placed in small pots $(10 \mathrm{~cm}$ in diameter by $20 \mathrm{~cm}$ height) for growth. Approximately 150 radish seeds were spread on the substrate of each pot. No fertilizers were added to the substrate during the experiment, again not to increase the number of potential interfering parameters, knowing that smectite-type clay contains enough $\mathrm{P}$ and $\mathrm{Ca}$ needed by the plants for the designed short-term experiment. To avoid any input from rain and aerosols, the experiment was conducted in the laboratory under a hood with a laminar flow of filtered air, on the basis of a weakly watering of the substrate with deionized water to maintain wet conditions. The room temperature was nearly constant at $23^{\circ} \mathrm{C}$ with a 12 -hour cycle of light and darkness. The chemical load of the deionized water was controlled, containing about $50 \mathrm{mg} / \mathrm{L}$ insoluble residue including the organic carbon. The containers, in which the substrate was disposed and gently compacted, were washed with dilute hydrochloric acid and with deionized water before use. Two times four pots 
were prepared for each species, and each sequence of pots was watered with $50 \mathrm{ml}$ of deionized water containing either $0 \mathrm{mg} / \mathrm{L}, 1000 \mathrm{mg} / \mathrm{L}, 2000 \mathrm{mg} / \mathrm{L}$ or $4000 \mathrm{mg} / \mathrm{L}$ of $\mathrm{AgNO}_{3}$ before seeding. No other chemical elements that could have interfered in the plant growth or in the transfer from substrate to plant were added during the experiment.

Thirty days after seeding, the plants were in a reasonably good shape and were harvested for chemical analysis. To constrain best the analytical uncertainty of the results, the following procedure was designed and applied: 1) the plants were grown in strictly the same conditions; 2) two containers of either no or the varied pollution degrees (1000, 2000 and $4000 \mathrm{mg} / \mathrm{L}$ of $\mathrm{AgNO}_{3}$ ) for each species ( $R$. sativus and $R$. raphanistrum) were systematically taken into account: 30 - 35 individual plants were harvested from each container; 3 ) each batch of 30 - 35 plants from each container was analyzed independently; and 4) the results of the two same batches were averaged. The chemical compositions of the plants reported in the table represent, therefore, analytical averages of the data from about 60 - 70 individual plants collected independently at the end of the growth experiment in two batches from two containers.

The collected plants were first washed five times with deionized water. The washing was followed by a mild ultrasonic treatment in a bath for about 10 minutes to remove any solid mineral particle that could still adhere at the surface of the plants after the washing, especially at the roots. After the ultrasonic treatment, the plants were washed again with deionized water. The roots of some of the plants were observed by optical and scanning electron microscopy for any visible presence of mineral particles, which was never the case. Alternatively, it cannot be ignored that an ultrasonic treatment potentially removes the chemical elements adsorbed at the root surfaces. The two approaches having advantages and drawbacks, the choice was purposely in favor of cleanness and analytical reproducibility, that is to say in favor of the gentle ultrasonic treatment. We considered the fact to lose some information by removing the adsorbed elements from root surfaces to be less deteriorated than measuring the potential contribution of unexpected mineral particles. Afterwards, each set of plant samples was prepared for chemical determinations.

The plants were dried at $60^{\circ} \mathrm{C}$ for 24 hours and weighed systematically on the same weight in the same temperature conditions. Then, they were ashed in a $\mathrm{Pt}$ crucible at about $600^{\circ} \mathrm{C}$ for $45 \mathrm{~min}$. The ash was transferred into a Teflon ${ }^{\circ}$ beaker and digested in ultrapure concentrated $\mathrm{HNO}_{3}$ at a temperature of about $70^{\circ} \mathrm{C}$ for 24 hours at least. The solution was then slowly evaporated to dryness by closing the beaker. Ten drops of $\mathrm{HClO}_{4}$ were added afterwards to ensure the complete dissolution of any remaining organic matter, and the aliquot was evaporated again to dryness. The solution for analysis was prepared by dissolving the dried material in a known volume of $1 \mathrm{~N}^{-N}$.

The elemental contents of the plants were determined using an ICP-AES (JY124 model from Jobin Yvon Instruments S.A.) for the major elements and some trace elements ( $\mathrm{Sr}$ and $\mathrm{Ba}$ ), and an ICP-MS (XSeries ${ }^{\mathrm{II}}$ model from Thermo Electron Corporation) with a collision chamber for the other trace elements, including the rareearth elements (REEs). Weakly analysis of the Gl-O and BE-N geostandards $[27,28]$ were carried out during the course of the study for calculation of the analytical precision that is of $\pm 2 \%, \pm 5 \%$ and $\pm 10 \%$ for the major, trace and REEs, respectively, with a $2 \sigma$ internal standard deviation. The individual analytical uncertainty was controlled as precisely as possible by duplicating the whole analytical procedure in two independent batches of plants and averaging them. It shall be remembered that the results were not biased by "soil heterogeneities" as the substrate consisted, on purpose, of a homogeneous claymineral type. Alternatively, we have postulated that any heterogeneity of the plants was "smoothened" by the high number of individuals (60 - 70) taken in two separate batches for each species at each pollution degree. Of course, possible manipulation errors cannot be excluded, but as they are difficult to quantify as such, we have tried to address that aspect by analyzing a high number of plant individuals. As the overall individual uncertainty is at the level of the analytical uncertainty, it can be assumed that no detectable manipulation mistake occurred during the experiment.

\section{Results}

After 30 days of growth, the height of the radish plants was about $20 \mathrm{~cm}$ and the diameter of the leaves about 2 $\mathrm{cm}$. Comparison between density and size of the plants in each pot showed that addition (called pollution hereafter) of $4000 \mathrm{mg} / \mathrm{L} \mathrm{Ag}$ to the substrate caused a reduction of the number of plants and of the size of the leaves relative to the plants collected from unpolluted or less polluted substrate. Metal toxicity may having varied impacts on plants that depend on the amounts incorporated by the plants (called contamination hereafter), and therefore on their ability to adjust to the potential toxicity created by the abnormal content of $\mathrm{Ag}$, the toxic metal. A routine evaluation of a metal contamination is the quantification of the metal added to the soil, if known, that gives its pollution degree. However, the possibility of a heterogeneous distribution of the metal contamination in the soil, even in an homogeneous substrate such as that used here, has been envisaged and we have also based the contamination on the amount of $\mathrm{Ag}$ incorporated by the plants, 
assuming that a higher Ag uptake (=contamination) corresponds to a higher Ag content in the root environment.

On the basis of this approach of the contamination scale, marked differences for the two plant species are visible (Table 1). In the case of $R$. sativus, the highest uptake of $\mathrm{Ag}$, that is to say the highest contamination in the plant, occurs at the $2000 \mathrm{mg} / \mathrm{L} \mathrm{Ag} \mathrm{level} \mathrm{of} \mathrm{pollution,}$ and surprisingly the lowest at the $4000 \mathrm{mg} / \mathrm{L} \mathrm{Ag}$ pollution level. Alternatively, the progressive uptake (=contamination) of $\mathrm{Ag}$ in $R$. raphanistrum follows the increased amount added to the substrate (=pollution) from 1000 to $4000 \mathrm{mg} / \mathrm{L} \mathrm{Ag}$. In summary, R. sativus incorporates 9.8 times more $\mathrm{Ag}$ than $R$. raphanistrum when grown in the unpolluted substrate, 3.2 times more $\mathrm{Ag}$ when grown in the substrate polluted by $1000 \mathrm{mg} / \mathrm{L}$ $\mathrm{AgNO}_{3}, 4.2$ times more $\mathrm{Ag}$ when grown in the substrate polluted by $2000 \mathrm{mg} / \mathrm{L}$, and 3 times less Ag when grown in the most polluted substrate at $4000 \mathrm{mg} / \mathrm{L}$ (Table 1). There is an average of 3 - 4 times more Ag taken up by $R$. Raphanistrum from polluted substrate whatever the pollution degree, while the difference was at about 10 times when grown in the non-polluted substrate. Two preliminary conclusions of the experiment are that: 1) there is a specific uptake (=contamination) of $\mathrm{Ag}$ by the two species of the same plant; and 2) the cultivated species incorporates more than the wild species except for the highest Ag substrate pollution.

\subsection{Uptake of Major Elements by the Plants}

Addition of $50 \mathrm{ml}$ of a solution containing various amounts of $\mathrm{Ag}$ to the substrate showed that $R$. sativus took up less major elements relative to the same species grown in the unpolluted substrate with the lowest uptake for the lowest Ag contamination, except for $\mathrm{Al}$ and Fe, which contents increased when the plants were grown in the polluted substrate (Table 1). The plants grown in the substrate polluted by an intermediate $\mathrm{AgNO}_{3}$ concentration of $2000 \mathrm{mg} / \mathrm{L}$ also took up most $\mathrm{Al}$ and Fe (Figure 1(a)).

In the case of $R$. raphanistrum, the amounts of $\mathrm{Si}, \mathrm{Na}$ and $\mathrm{K}$ taken up by the plants are systematically less when Ag pollution increased, therefore when contamination increased. The other elements were taken up more (Figure 2(a)). Again when considering the total amounts of major elements taken up, they were lower in the plants from polluted substrates than in those from unpolluted substrate, with a continuous decrease from unpolluted substrate to the most polluted (Table 1).

In comparing the amounts of the major elements picked up by both species, the wild species $R$. raphanistrum is systematically taking up less elements than the cultivated $R$. sativus, the difference being as much as $16.7 \%$ when grown in the substrate polluted by 2000 $\mathrm{mg} / \mathrm{L} \mathrm{AgNO}_{3}$.

\subsection{Trace-Element Transfer into the Plants}

$R$. sativus took up systematically less $\mathrm{V}, \mathrm{Cr}, \mathrm{Pb}, \mathrm{Rb}$ and $\mathrm{Sr}$, and more $\mathrm{Cu}$ and $\mathrm{Ag}$, when the $\mathrm{Ag}$ pollution increased in the substrate (Table 1). For all other trace elements, the amounts either increased or decreased irregularly in the plants (Figure 1(b)). Also, the systematic low $\mathrm{Rb}$ pick up is negatively correlated with the Ag addition to the substrate, and the reverse can be observed for Sr. The trace elements picked up by $R$. raphanistrum are systematically higher when grown in the polluted substrate, except for $\mathrm{Rb}$ and $\mathrm{Cr}$ in one case (Table 1; Figure 2(b)).

\subsection{Contents of Rare-Earth Elements in the Plants}

The total concentration of REEs increased systematically in $R$. sativus grown in the polluted substrate. The REE content was almost 12 times more in the plants grown in the substrate polluted by $2000 \mathrm{mg} / \mathrm{L} \mathrm{AgNO}_{3}$ than in the plants grown in the unpolluted substrate. At the highest $\mathrm{AgNO}_{3}$ pollution of $4000 \mathrm{mg} / \mathrm{L}$, the REE contents were lower by about $34 \%$. Normalization of the REE contents of $R$. sativus collected from each substrate, relative to those of the unpolluted smectite substrate, provide a depleted content in the middle REEs (MREEs) with a positive anomaly in Eu (Figure 3(a)). Normalized to the REE patterns of the plants grown in the unpolluted substrate, the distribution patterns of the REEs in the plants from polluted substrates with different concentrations of $\mathrm{Ag}$ are quite similar, with an increase in the light REEs (LREEs) from $\mathrm{La}$ to $\mathrm{Eu}$, similar amounts from $\mathrm{Eu}$ to $\mathrm{Er}$ and a slight increase for Yb (Figure 4(a)). These patterns are also characterized by a systematic negative Eu anomaly.

The distribution patterns of the REEs of $R$. raphanistrum grown in the polluted substrates are similar to those of $R$. sativus (Figure 3(b)) with, however, much lower contents. Normalization of the REE contents of the plants collected from each polluted substrate to the REEs from the same species grown in the unpolluted smectite substrate shows patterns that are again similar to those of $R$. sativus, with a significant positive anomaly in Eu. The patterns are also slightly more scattered than those of $R$. sativus (Figure 4(b)).

\section{Discussion}

Before discussing the changes of the element uptakes by the two species of radish, it is probably appropriate to reiterate here the objectives of this experiment. The goal is the examination of the behavior of two plant species 
Table 1. Chemical composition of Raphanus sativus and Raphanus raphanistrum plants collected from the unpolluted substrate and substrates polluted by 1000,2000 and $4000 \mathrm{mg} / \mathrm{L}$ of $\mathrm{AgNO}_{3}$. The concentrations are expressed in $\mathrm{mg} / \mathrm{g}$ of $\mathrm{dried}$ plant for the major elements and in $\mu \mathrm{g} / \mathrm{g}$ of dried plant for the trace and rare-earth elements.

\begin{tabular}{|c|c|c|c|c|c|c|c|c|}
\hline \multirow{2}{*}{$\begin{array}{c}\text { Elements } \\
\text { in } \mathrm{mg} / \mathrm{g}\end{array}$} & \multicolumn{4}{|c|}{ Raphanus sativus } & \multicolumn{4}{|c|}{ Raphanus raphanistrum } \\
\hline & $\begin{array}{l}0 \mathrm{mg} / \mathrm{L} \\
\mathrm{AgNO}_{3}\end{array}$ & $\begin{array}{c}1000 \mathrm{mg} / \mathrm{L} \\
\mathrm{AgNO}_{3}\end{array}$ & $\begin{array}{c}2000 \mathrm{mg} / \mathrm{L} \\
\mathrm{AgNO}_{3}\end{array}$ & $\begin{array}{c}4000 \mathrm{mg} / \mathrm{L} \\
\mathrm{AgNO}_{3}\end{array}$ & $\begin{array}{l}0 \mathrm{mg} / \mathrm{L} \\
\mathrm{AgNO}_{3}\end{array}$ & $\begin{array}{c}1000 \mathrm{mg} / \mathrm{L} \\
\mathrm{AgNO}_{3}\end{array}$ & $\begin{array}{c}2000 \mathrm{mg} / \mathrm{L} \\
\mathrm{AgNO}_{3}\end{array}$ & $\begin{array}{c}4000 \mathrm{mg} / \mathrm{L} \\
\mathrm{AgNO}_{3}\end{array}$ \\
\hline $\mathrm{Si}$ & 0.20 & 0.07 & 0.03 & 0.08 & 0.13 & 0.11 & 0.11 & 0.11 \\
\hline $\mathrm{Al}$ & 0.95 & 0.89 & 2.51 & 0.77 & 0.02 & 1.16 & 1.23 & 0.80 \\
\hline $\mathrm{Mg}$ & 5.42 & 4.62 & 5.49 & 4.89 & 4.24 & 5.22 & 4.58 & 4.84 \\
\hline $\mathrm{Ca}$ & 18.4 & 13.3 & 15.7 & 18.5 & 5.14 & 12.5 & 12.6 & 13.5 \\
\hline $\mathrm{Fe}$ & 0.19 & 0.13 & 0.34 & 0.08 & 0.01 & 0.18 & 0.22 & 0.15 \\
\hline $\mathrm{Mn}$ & 0.16 & 0.10 & 0.12 & 0.12 & 0.03 & 0.09 & 0.10 & 0.07 \\
\hline $\mathrm{Na}$ & 6.29 & 5.81 & 5.34 & 3.91 & 9.55 & 6.06 & 4.78 & 4.51 \\
\hline K & 27.9 & 20.9 & 18.4 & 13.0 & 39.2 & 20.6 & 15.7 & 16.5 \\
\hline $\mathrm{P}$ & 7.80 & 7.45 & 7.17 & 7.40 & 2.65 & 7.06 & 6.56 & 7.46 \\
\hline Total MEs & 67.31 & 53.27 & 55.10 & 48.75 & 60.97 & 52.98 & 45.88 & 47.94 \\
\hline \multicolumn{9}{|l|}{ in $\mu \mathrm{g} / \mathrm{g}$} \\
\hline $\mathrm{V}$ & 3.86 & 1.33 & 3.85 & 2.81 & 1.18 & 2.15 & 6.24 & 2.58 \\
\hline $\mathrm{Cr}$ & 1.41 & 0.75 & 0.87 & 1.12 & 1.15 & 0.85 & 1.29 & 1.62 \\
\hline Co & 0.39 & 0.36 & 0.43 & 0.64 & 0.12 & 0.33 & 0.45 & 0.51 \\
\hline $\mathrm{Ni}$ & 1.93 & 1.73 & 1.69 & 2.46 & 0.65 & 1.72 & 2.61 & 2.23 \\
\hline $\mathrm{Cu}$ & 5.21 & 5.45 & 11.2 & 5.25 & 0.90 & 2.85 & 6.59 & 4.00 \\
\hline $\mathrm{Zn}$ & 184 & 203 & 183 & 175 & 49.1 & 174 & 181 & 185 \\
\hline $\mathrm{Rb}$ & 18.4 & 11.8 & 8.92 & 6.58 & 28.5 & 15.7 & 10.1 & 11.3 \\
\hline $\mathrm{Sr}$ & 246 & 182 & 227 & 282 & 57.6 & 171 & 180 & 195 \\
\hline $\mathrm{Zr}$ & 1.05 & 0.91 & 1.79 & 0.97 & bdl & 0.91 & 1.43 & 1.07 \\
\hline $\mathrm{Ba}$ & 339 & 332 & 346 & 342 & 68.2 & 274 & 327 & 329 \\
\hline $\mathrm{Pb}$ & 95.0 & 1.18 & 2.09 & 12.31 & 0.03 & 1.35 & 3.14 & 1.06 \\
\hline Th & 0.45 & 0.09 & 0.58 & 0.14 & bdl & 0.26 & 0.58 & 0.04 \\
\hline $\mathrm{U}$ & 0.14 & 0.13 & 0.21 & 0.16 & 0.03 & 0.31 & 0.70 & 0.33 \\
\hline Ag & 0.69 & 3315 & 5287 & 2564 & 0.07 & 1032 & 1236 & 7483 \\
\hline $\mathrm{La}$ & 0.30 & 2.06 & 4.78 & 3.21 & 1.48 & 3.75 & 7.10 & 3.16 \\
\hline $\mathrm{Ce}$ & 0.57 & 2.95 & 8.54 & 5.56 & 2.47 & 5.19 & 13.0 & 4.66 \\
\hline $\operatorname{Pr}$ & 0.07 & 0.34 & 0.89 & 0.59 & 0.36 & 0.60 & 1.28 & 0.50 \\
\hline $\mathrm{Nd}$ & 0.27 & 1.10 & 2.93 & 1.96 & 1.28 & 1.93 & 4.25 & 1.62 \\
\hline $\mathrm{Sm}$ & 0.06 & 0.21 & 0.53 & 0.35 & 0.27 & 0.29 & 0.71 & 0.33 \\
\hline $\mathrm{Eu}$ & 0.01 & 0.02 & 0.06 & 0.04 & 0.02 & 0.04 & 0.08 & 0.03 \\
\hline Gd & 0.06 & 0.14 & 0.38 & 0.26 & 0.31 & 0.23 & 0.58 & 0.19 \\
\hline $\mathrm{Tb}$ & 0.01 & 0.02 & 0.06 & 0.04 & 0.04 & 0.03 & 0.09 & 0.03 \\
\hline Dy & 0.05 & 0.10 & 0.30 & 0.20 & 0.19 & 0.17 & 0.46 & 0.15 \\
\hline Ho & 0.01 & 0.02 & 0.06 & 0.04 & 0.04 & 0.03 & 0.09 & 0.03 \\
\hline Er & 0.03 & 0.06 & 0.18 & 0.12 & 0.10 & 0.10 & 0.27 & 0.09 \\
\hline $\mathrm{Tm}$ & 0.004 & 0.01 & 0.03 & 0.02 & 0.02 & 0.02 & 0.04 & 0.01 \\
\hline $\mathrm{Yb}$ & 0.02 & 0.07 & 0.18 & 0.12 & 0.10 & 0.12 & 0.27 & 0.11 \\
\hline $\mathrm{Lu}$ & 0.003 & 0.01 & 0.03 & 0.02 & 0.01 & 0.02 & 0.04 & 0.02 \\
\hline Total REEs & 1.46 & 7.16 & 18.95 & 12.53 & 6.59 & 12.52 & 28.26 & 10.93 \\
\hline $\mathrm{Si} / \mathrm{Al}$ & 0.22 & 0.08 & 0.01 & 0.10 & 0.65 & 0.09 & 0.09 & 0.14 \\
\hline $\mathrm{Na} / \mathrm{K}$ & 0.23 & 0.28 & 0.29 & 0.30 & 0.24 & 0.29 & 0.30 & 0.27 \\
\hline $\mathrm{Ca} / \mathrm{Sr}$ & 74.8 & 73.1 & 69.2 & 65.6 & 89.2 & 73.1 & 70.0 & 69.2 \\
\hline $\mathrm{K} / \mathrm{Rb}$ & 1516 & 1771 & 2063 & 1976 & 1375 & 1312 & 1554 & 1460 \\
\hline
\end{tabular}




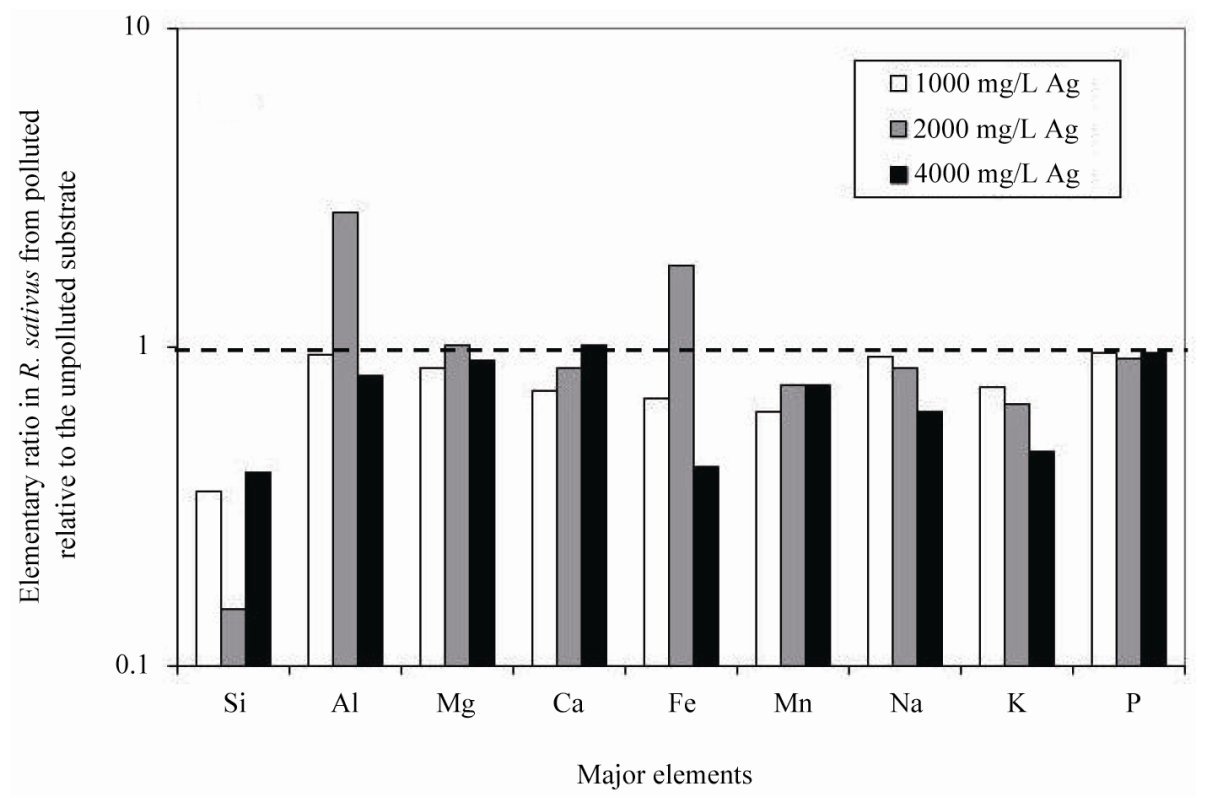

(a)

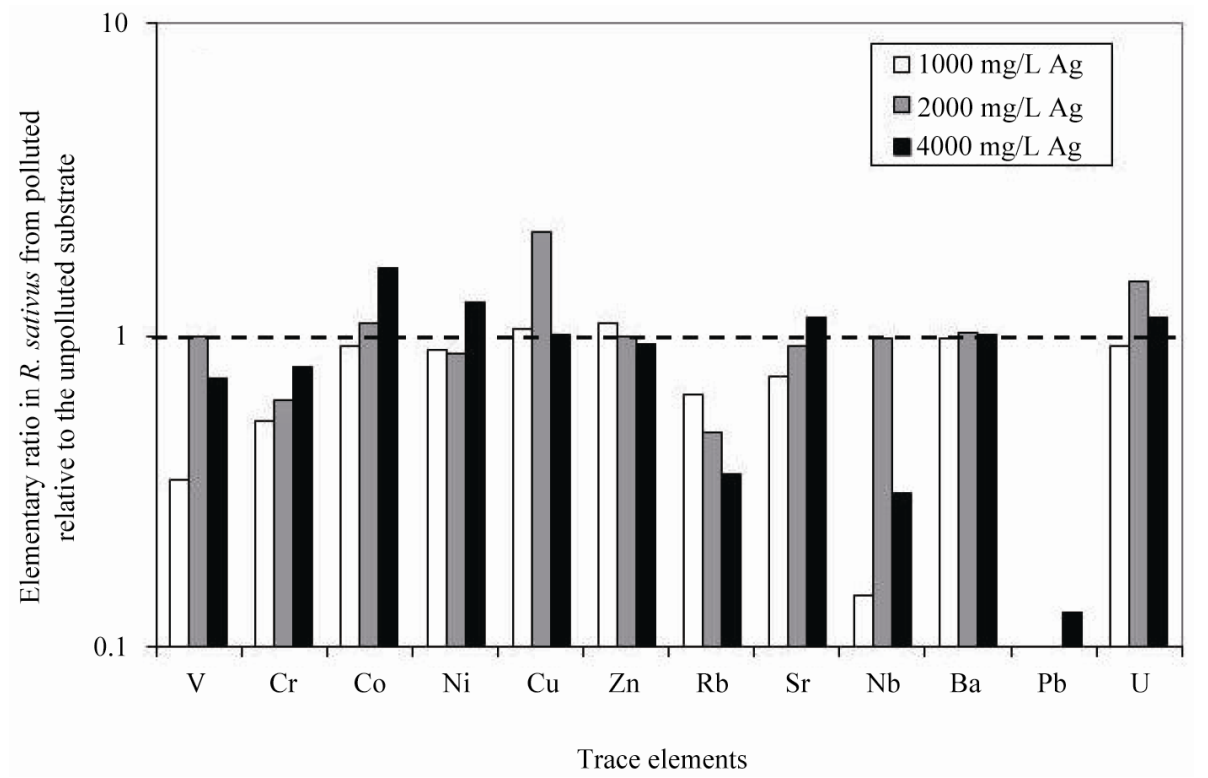

(b)

Figure 1. (a) Ratios among the major-element concentrations in Raphanus sativus from $\mathrm{AgNO}_{3}$ polluted substrates relative to the same elements in the species from unpolluted substrate; (b) Ratios among the trace-element concentrations in Raphanus sativus from $\mathrm{AgNO}_{3}$ polluted substrates relative to the same elements in the species from unpolluted substrate. In both cases, an identical uptake is shown by a ratio of 1 .

growing in a homogeneous mono-mineralic clay-type substrate extremely polluted by Ag. The study was designed to focus on the initial mineral-to-plant elemental transfers depending on the degree of Ag pollution of the substrate, and not to address biological and metabolic aspects of plants growing on natural soils. Providing some understanding on how two different plant species select the nutrient elements from an Ag-polluted monomineralic substrate was also among the topics of interest.
The mobility of nutrients from soils to plants generally depends on the selective pick up by the plants, which in turn depends on the $\mathrm{pH}$ and solubility of the soil minerals, and more importantly on the activity of the microorganisms that may contribute to the mineral dissolution and the enzymes to the element transfers. These transfers were evaluated here for two species of plants that grew in the same substrate polluted by increasing amounts of $\mathrm{AgNO}_{3}$ by the soil solution, but depleted in microorgan- 


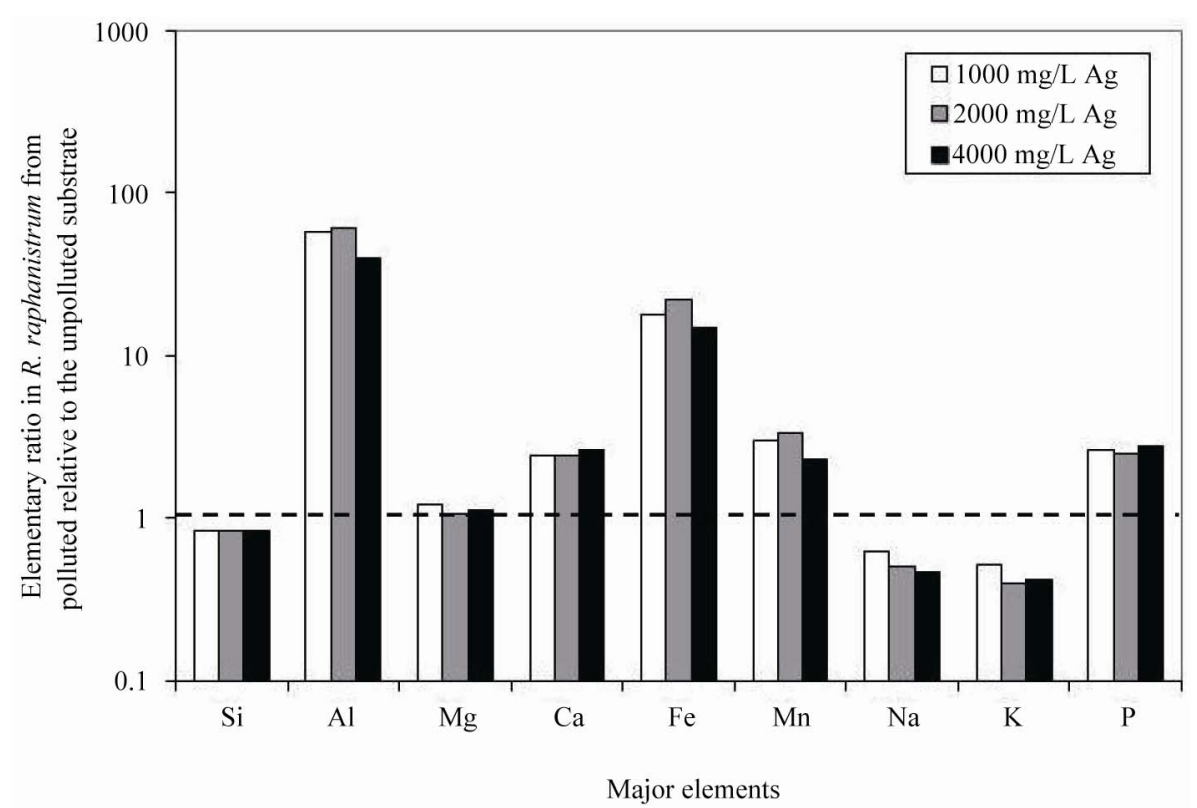

(a)

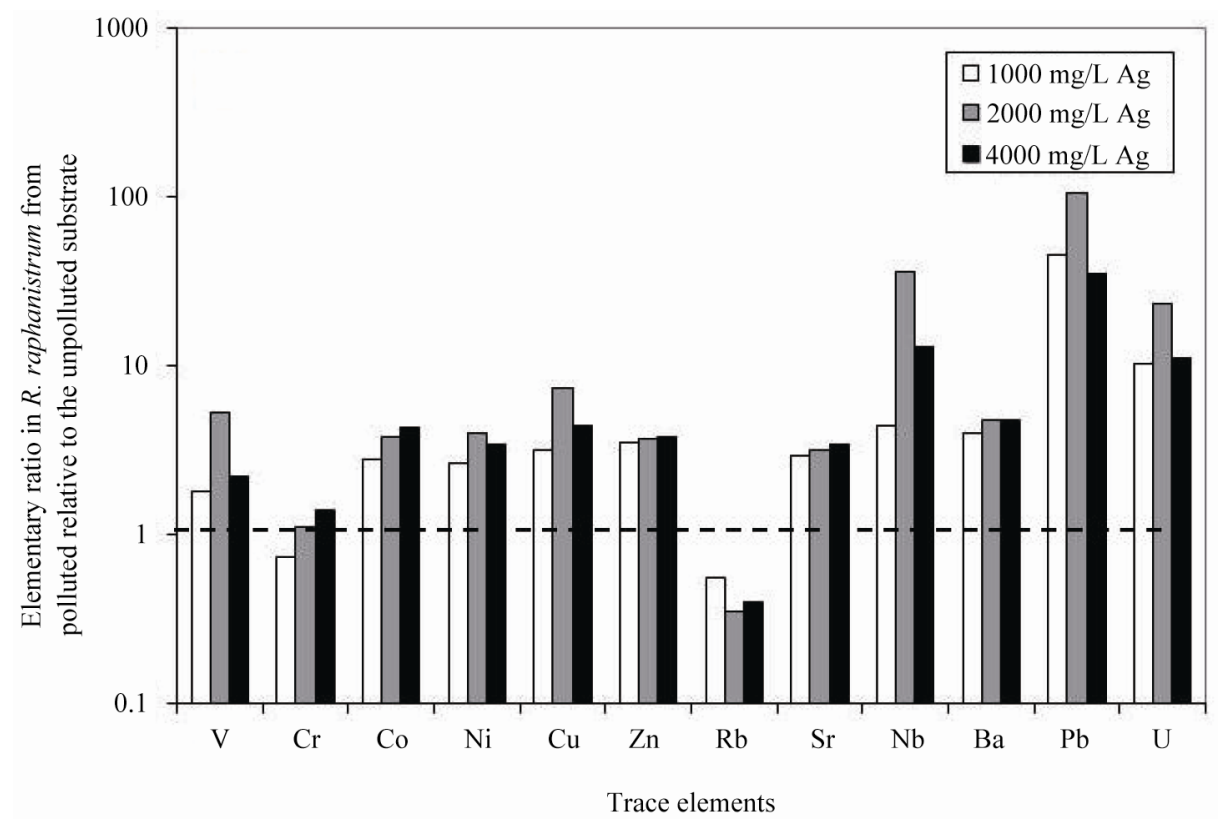

(b)

Figure 2. (a) Ratios among the major-element concentrations in Raphanus raphanistrum from $\mathrm{AgNO}_{3}$ polluted substrates relative to the same elements in the species from unpolluted substrate; (b) Trace-element concentrations in Raphanus raphanistrum from $\mathrm{AgNO}_{3}$ polluted substrates relative to the same element concentrations in the same species from unpolluted substrate. In both cases, an identical uptake is shown by a ratio of 1 .

isms during the experiment on the basis of the results by Semhi et al. [25]. It was then compared to the amounts of the same elements picked up by the same plants grown simultaneously in the unpolluted reference substrate. The analyzed elements were transferred from substrate to plant in the following decreasing order: $\mathrm{P}>\mathrm{K}>\mathrm{Ca}>\mathrm{Mn}$ $>\mathrm{Mg}>\mathrm{Na}>\mathrm{Al}>\mathrm{Si}$ for the major elements, and $\mathrm{Pb}>\mathrm{Zn}$ $>\mathrm{Rb}>\mathrm{Cu}>\mathrm{Sr}>\mathrm{Ba}$ for the metals. Pollution of the sub- strate with $1000 \mathrm{mg} / \mathrm{L}$ of $\mathrm{AgNO}_{3}$ decreased the uptakes of $\mathrm{Si}, \mathrm{Mn}, \mathrm{Na}, \mathrm{K}, \mathrm{Ca}, \mathrm{Mg}, \mathrm{P}$ and the REEs by $R$. sativus, and increased the uptake of most elements picked up by $R$. raphanistrum, except $\mathrm{Si}, \mathrm{K}$ and $\mathrm{Na}$. Addition of 2000 $\mathrm{mg} / \mathrm{L}$ of $\mathrm{AgNO}_{3}$ decreased the pick up of most elements by $R$. sativus, except $\mathrm{Al}$ and $\mathrm{Fe}$, while most elements were taken up in higher amounts by $R$. raphanistrum, except $\mathrm{Si}, \mathrm{Na}$ and $\mathrm{K}$. When the substrate was polluted by 


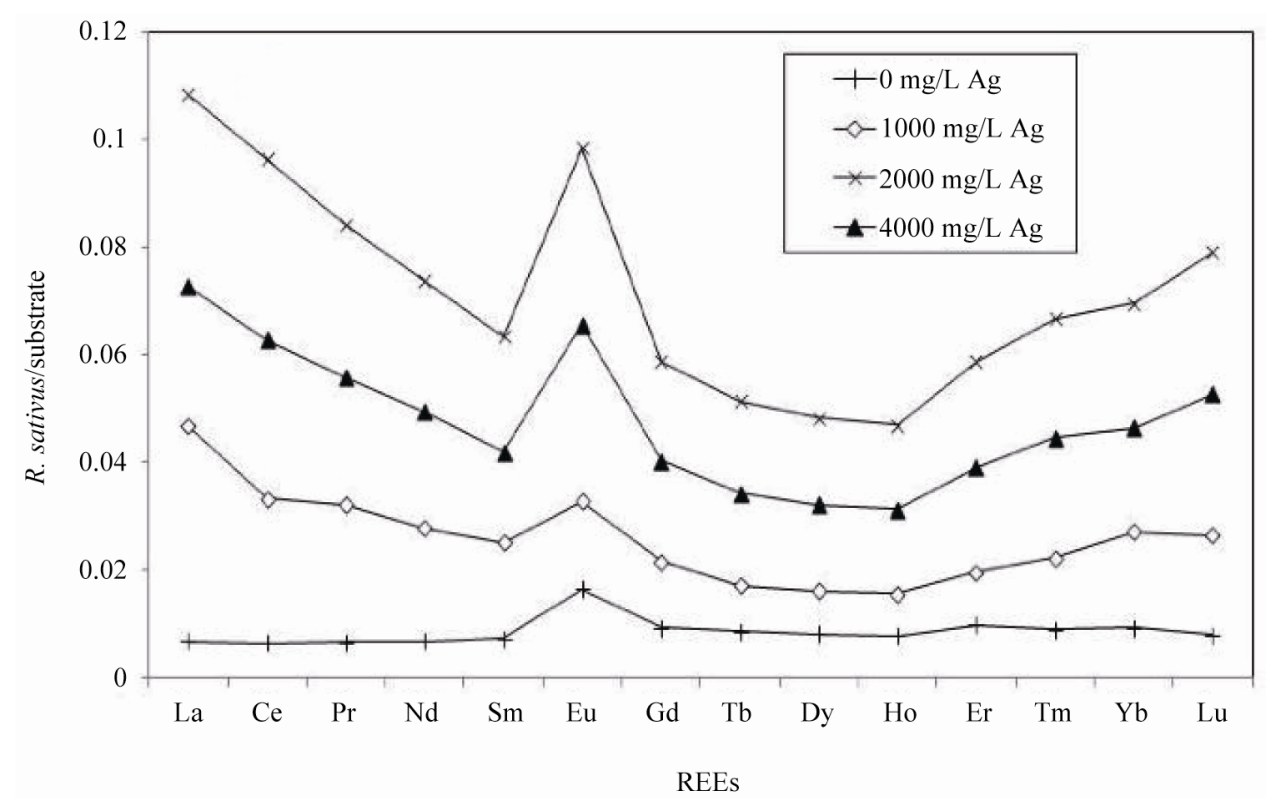

(a)

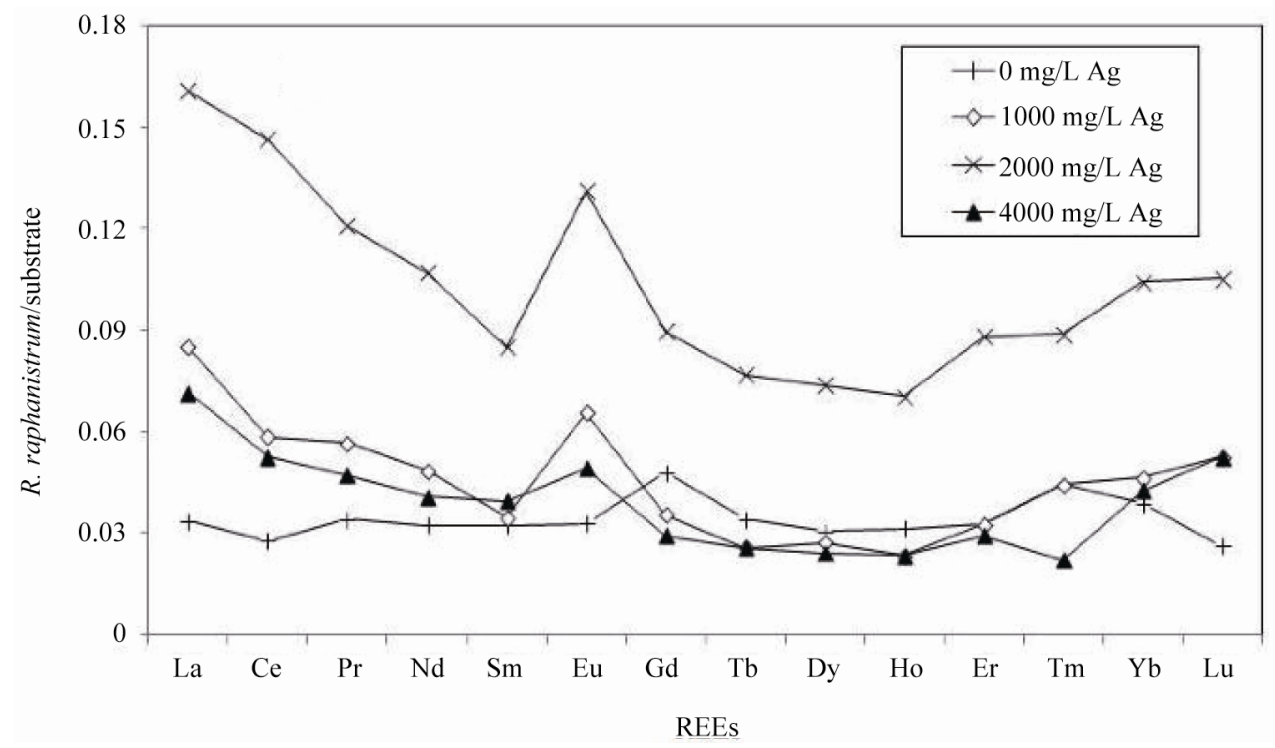

(b)

Figure 3. (a) REE concentrations of Raphanus sativus normalized to the REE concentrations in the smectite substrate of Semhi et al. (2009); (b) REE concentrations of Raphanus raphanistrum normalized to the same REE concentrations in the smectite substrate.

as much as $4000 \mathrm{mg} / \mathrm{L}$ of $\mathrm{AgNO}_{3}$, R. sativus incorporated lower amounts of the elements, except $\mathrm{Ca}$ which amounts remained unchanged. For $R$. raphanistrum, the taking up of most elements increased in the presence of as much as $4000 \mathrm{mg} / \mathrm{L}$ of $\mathrm{AgNO}_{3}$, except $\mathrm{Si}, \mathrm{Na}$ and $\mathrm{K}$.

\subsection{Element Transfers from Substrate to Plants}

The amounts of most major and trace elements including the REEs decreased in R. sativus grown in the less polluted substrate $\left(1000 \mathrm{mg} / \mathrm{L} \mathrm{AgNO}_{3}\right)$ compared to the same species grown in the unpolluted substrate. For $R$. raphanistrum grown in the same polluted substrate, the contents of most elements increased relative to those in the plants from the unpolluted substrate; $\mathrm{Si}, \mathrm{K}, \mathrm{Na}$ and $\mathrm{Rb}$ decreased. The uptake of the elements by the plants from less polluted substrate $\left(1000 \mathrm{mg} / \mathrm{L} \mathrm{AgNO}_{3}\right)$ depends on the species, one taking up more and the other less. At the intermediate pollution concentration of 2000 $\mathrm{mg} / \mathrm{L}$ of $\mathrm{AgNO}_{3}$, the content of most major and trace elements decreased in $R$. sativus, except for the increasing $\mathrm{Al}, \mathrm{Fe}, \mathrm{Th}, \mathrm{Ag}$ and $\mathrm{U}$, and for the unchanged $\mathrm{Mg}, \mathrm{Co}$, 


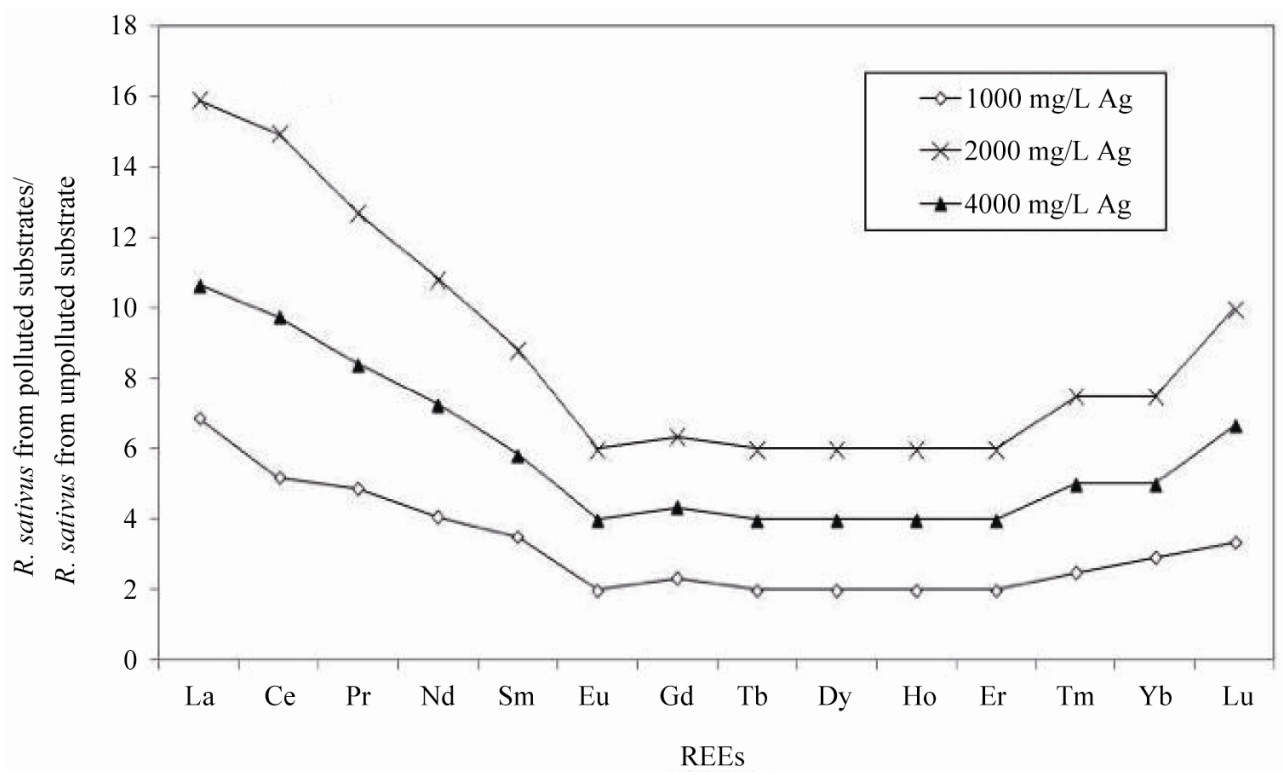

(a)

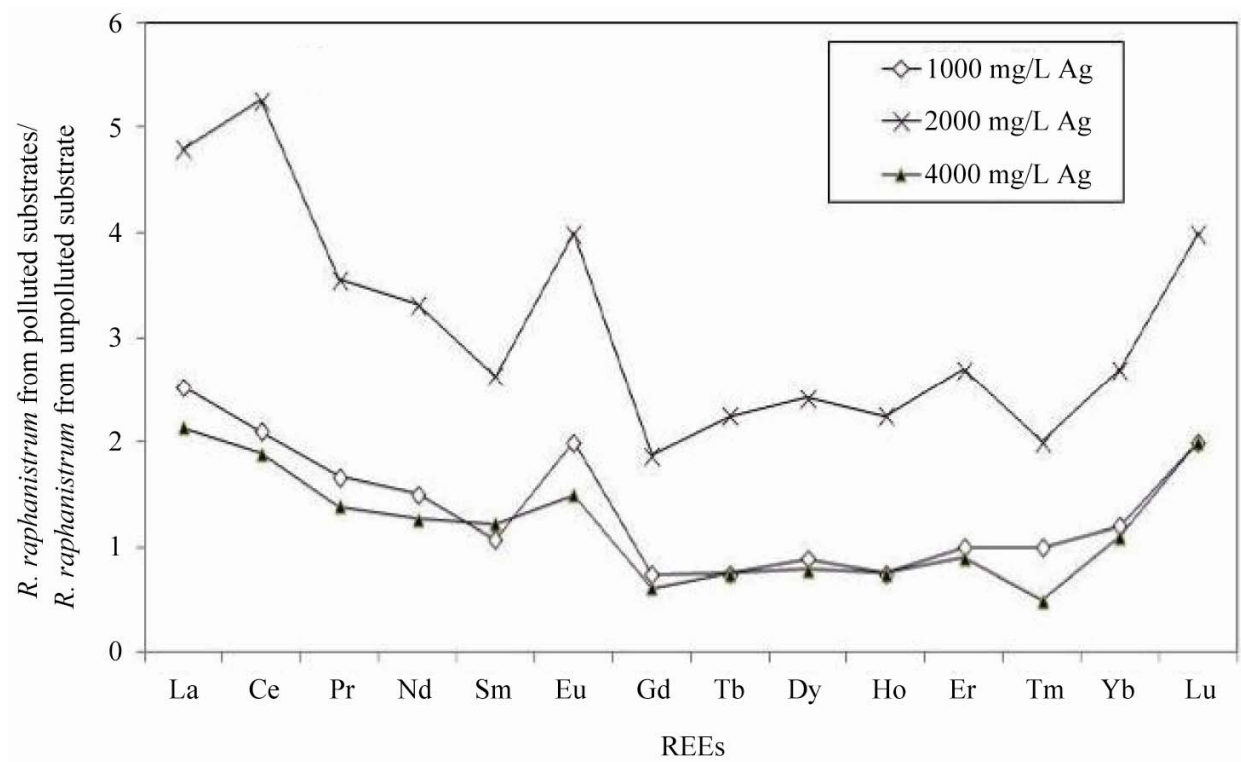

(b)

Figure 4. (a) REE composition of Raphanus sativus from the $\mathrm{AgNO}_{3}$ polluted substrates normalized to the REE concentrations in the same species from unpolluted substrate; (b) REE composition of Raphanus raphanistrum from the AgNO pol- $^{-}$ luted substrate normalized to the REE concentrations in the same species from unpolluted substrate.

$\mathrm{V}, \mathrm{Nb}, \mathrm{Zn}$ and the total $\mathrm{REE}$ contents. In $R$. raphanistrum, the content of most elements increased relative to the same species collected from unpolluted substrate, except for the decreasing $\mathrm{K}, \mathrm{Na}, \mathrm{Si}$ and $\mathrm{Rb}$. Again the uptake appears to be species dependent. After addition of the high Ag pollution $\left(4000 \mathrm{mg} / \mathrm{L}\right.$ of $\mathrm{AgNO}_{3}$ ) to the substrate, the contents of most major and trace elements decreased in $R$. sativus, except for the unchanged $\mathrm{Ca}, \mathrm{Ba}$, $\mathrm{Cu}$ and $\mathrm{Cd}$, and for the increasing $\mathrm{Sr}, \mathrm{Co}, \mathrm{Ni}, \mathrm{U}$ and $\mathrm{Ag}$ relative to the species from the unpolluted substrate. For R. raphanistrum collected from $4000 \mathrm{mg} / \mathrm{L} \mathrm{AgNO}_{3}$ pol- luted substrate, the contents of most elements increased relative to those in the same species from unpolluted substrate, except the decreasing $\mathrm{Si}, \mathrm{K}, \mathrm{Na}$ and $\mathrm{Rb}$.

The response to an increasing Ag pollution obviously depends on the plant species, $R$. sativus picking up higher amounts of $\mathrm{Ag}$ at the two lower contamination concentrations than $R$. raphanistrum, which picked up more $\mathrm{Ag}$ at the highest pollution concentration $(4000 \mathrm{mg} / \mathrm{L}$ of $\mathrm{AgNO}_{3}$ ). The highest enrichment in $\mathrm{Ag}$ in $R$. sativus was observed in the plants collected from substrate polluted with $2000 \mathrm{mg} / \mathrm{L}$ of $\mathrm{AgNO}_{3}$ and the highest enrichment in 
$\mathrm{Ag}$ in $R$. raphanistrum was observed in the plants collected from substrate polluted with two times more Ag $(4000 \mathrm{mg} / \mathrm{L})$. This difference in the accumulation of $\mathrm{Ag}$ by two species reflects a variable impact of $\mathrm{Ag}$ on their rhizosphere.

One of the most abundant elements in soils is $\mathrm{Si}$ that has here in the clay substrate an antagonistic behavior with $\mathrm{Al}$ and $\mathrm{Fe}$ in $\mathrm{R}$. sativus from substrate polluted by $2000 \mathrm{mg} / \mathrm{L}$ of $\mathrm{AgNO}_{3}$. The higher $\mathrm{Al}$ accumulation in the plants induces a decrease in the mobility of $\mathrm{Si}$, and a correlative increase in that of $\mathrm{Fe}$ and $\mathrm{Al}$ relative to the same elements in plants collected from other substrates. The content in Fe increased by about $82 \%$ and that in $\mathrm{Al}$ by about $165 \%$ relative to the same species grown in the unpolluted substrate. These changes correlate to higher Ag uptake by the plants. As for $R$. sativus, the highest mobility of $\mathrm{Al}$ and $\mathrm{Fe}$ from substrate to the plants was found when the substrate was polluted by $2000 \mathrm{mg} / \mathrm{L}$ $\mathrm{AgNO}_{3}$, whereas the highest Ag accumulation in $R$. rap-

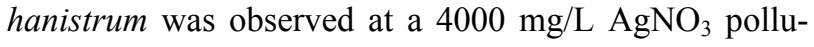
tion.

The bioavailability of $\mathrm{Al}$ and $\mathrm{Fe}$ in the rhizosphere is influenced by the ionic species and concentrations, which both depend on $\mathrm{pH}$ and chemical composition of root exudates [29]. Aluminium is soluble and biologically available in acidic $(\mathrm{pH}<5.5)$ soils and waters: weathering with an acidification to $\mathrm{pH}$ below 5.5 increases the dissolution kinetics of Al. Iron can be picked up from soil by complexation with organic acids and phenolics in the rhizosphere, or with phytosiderophores [30]. Also, microbial production and subsequent degradation of siderophores may have an impact on the Fe availability of plants. However, these processes did probably not occur here due to the lack or limited occurrence of organic matter in the substrate.

Since heavy metals such as Ag are picked up from soils and transported to cells via plant-nutrient transporters [31] or membrane channels that are not necessarily selective, the mobility decrease of most nutrients can result from an interference between $\mathrm{Ag}$ transport and nutrient uptake. Complexation of $\mathrm{Ag}$ with active sites on enzymes (in the membrane) also alters the membrane permeability [32]. Silver can block the ion uptake at the plasma-lemma interface by interfering with cation recognition sites, except the $\mathrm{Ca}$ recognition sites. Changes in $\mathrm{pH}$ and reduction-oxidation potential of the rhizosphere may explain a decrease in the production of ligands and a reduction in the transfer of many nutrients from soils to plants. Such possible potential for Ag to block recognition sites of the plant membranes can be efficiently traced by comparing the ratios of elements that have close behaviors, but not necessarily similar contents in minerals or in a wider sense in soils. This is the case for $\mathrm{K}$ and $\mathrm{Rb}$ on one hand and for $\mathrm{Ca}$ and $\mathrm{Sr}$ on the other.
This differential behavior will be examined below.

The high accumulation of $\mathrm{Fe}$ and $\mathrm{Al}$ in the plants grown during this study, either beneficial or toxic, is probably due to their high content in the clay substrate. Neither $R$. sativus nor $R$. raphanistrum collected from substrate polluted by $2000 \mathrm{mg} / \mathrm{L}$ of $\mathrm{AgNO}_{3}$ were characterized by an enrichment in $\mathrm{Fe}$ and $\mathrm{Al}$ relative to the same species grown in the unpolluted substrate. This important availability of $\mathrm{Fe}$ and $\mathrm{Al}$ may result from a variation in the biomass and the microbial processes induced by variations in $\mathrm{pH}$, which in turn could have been induced by increased root exudation of organic acids [33]. There was probably also an important production of specific ligands in the rhizosphere that facilitated the Fe and Al transfer from the soil solution to the plants. The high mobility of these elements in the presence of the $\mathrm{Ag}$ contamination may also result from: 1) a heterogeneity in the bacterial population combined with the fact that some microorganic populations could be more resistant to contaminants especially at the $2000 \mathrm{mg} / \mathrm{L} \mathrm{AgNO}_{3}$ pollution, and 2) a heterogeneity in the produced ligands specific to the available nutrients. In experiments with bacteria, mica and feldspar conducted by Barker et al. [34], there was a direct correlation between the production of microbial organic ligand and an increased release of $\mathrm{Si}, \mathrm{Al}$ and $\mathrm{Fe}$.

\subsection{Selective Elemental Uptake by Plants Depending on the Degree of Ag Contamination}

The plant selectivity causing element fractionations can be evaluated by comparing elements that are chemically similar. In the present case, we have focused on changes of the $\mathrm{Ca} / \mathrm{Sr}$ and $\mathrm{K} / \mathrm{Rb}$ ratios, as well as on the REE distribution (Table 1). Changes in the take up selectivity of plants as a result of the presence of contaminants in soils have an economic impact in agricultural production when occurring to plants grown for human consumption. Recognition of the potential blocking action of Ag that was mentioned above raises immediate questions about growing vegetables in soils variably polluted by heavy metals and about the necessary uptake of nutrients. The impact of any metal contamination on the nutrient uptake by plants can, in essence, be evaluated by examining the variations of elements chemically similar to major nutrients. The potential of Ag blocking recognition sites of plant membranes increases the interest of examining the behavior of such elements. Variable fractionation of REEs that are also chemically very close provides an additional interesting control of the selectivity of plants growing in soils polluted by Ag, but probably also by other heavy metals such as $\mathrm{Cd}$ and $\mathrm{Pb}$. 


\subsubsection{The K/Rb Ratio}

The concentrations of $\mathrm{K}$ and $\mathrm{Rb}$ decreased in R. sativus grown in the smectite substrates polluted by Ag relative to the same species from unpolluted substrate. An important increase of the $\mathrm{K} / \mathrm{Rb}$ ratio was found for the plants collected from substrate polluted by $2000 \mathrm{mg} / \mathrm{L}$ of $\mathrm{AgNO}_{3}$, the uptake of $\mathrm{Rb}$ being reduced relative to that of $\mathrm{K}$ when the species incorporated more Ag.

In $R$. raphanistrum grown in all substrates, it can be seen that, although the decrease in either $\mathrm{Rb}$ or $\mathrm{K}$, the $\mathrm{K} / \mathrm{Rb}$ ratio increased in the plants grown in the substrates polluted by 2000 and $4000 \mathrm{mg} / \mathrm{L}$ of $\mathrm{AgNO}_{3}$, that is to say that the ratio increased in the plants when $\mathrm{Ag}$ increased in the substrate, because of a selective uptake of $\mathrm{K}$ relative to $\mathrm{Rb}$. The mobility of both $\mathrm{K}$ and $\mathrm{Rb}$ was reduced due to a higher presence of $\mathrm{Ag}$ in the substrate, but this reduction is more important for $\mathrm{Rb}$ than for $\mathrm{K}$, as it was for $R$. sativus. The $\mathrm{K} / \mathrm{Rb}$ ratio remained unchanged in the plants from substrate polluted by $1000 \mathrm{mg} / \mathrm{L}$ of $\mathrm{AgNO}_{3}$, where the reduction of the $\mathrm{K}$ mobility was similar to that of the Rb. There is no selectivity in the uptake of $\mathrm{K}$ and $\mathrm{Rb}$ at this level of pollution. Variations in the ratio only occurred in the plants grown in the highly polluted substrate, which confirms the impact of contaminants on the enzymes and the fixation sites of the elements.

\subsubsection{The Sr/Ca Ratio}

In $R$. sativus grown in the substrate polluted by 1000 $\mathrm{mg} / \mathrm{L}$ of $\mathrm{AgNO}_{3}$, the contents of both $\mathrm{Sr}$ and $\mathrm{Ca}$ decreased at the same rate relative to the species grown in the unpolluted substrate, leaving the $\mathrm{Sr} / \mathrm{Ca}$ ratio unchanged. In the same plants from substrate polluted by $2000 \mathrm{mg} / \mathrm{L}$ of $\mathrm{AgNO}_{3}$ that were contaminated the most by $\mathrm{Ag}$, the mobility of $\mathrm{Sr}$ was reduced relative to that of $\mathrm{Ca}$, while the $\mathrm{Sr} / \mathrm{Ca}$ ratio remained unchanged again.

In $R$. sativus grown in the substrate polluted by 4000 $\mathrm{mg} / \mathrm{L} \mathrm{AgNO}_{3}$, the $\mathrm{Sr}$ concentration increased while the Ca concentration remained unchanged, which increased slightly the $\mathrm{Sr} / \mathrm{Ca}$ ratio. In $R$. raphanistrum collected from variably polluted substrate, the contents of either $\mathrm{Sr}$ or $\mathrm{Ca}$ increased when $\mathrm{Ag}$ contamination in the plants increased, with more mobility for $\mathrm{Sr}$ than for $\mathrm{Ca}$, inducing an increase in the $\mathrm{Sr} / \mathrm{Ca}$ ratios.

\subsubsection{The REE Contents and Distribution}

As for elements with similar behaviors, potential clues of plant-soil interactions can be derived from examination of both the REE contents and distribution in plants or parts of plants, relative to the substrate normalized distribution of each lanthanide, e.g., by Semhi et al. [35] and references therein. For instance, REE concentrations in plants are influenced by factors such as the soil mineral composition and plant types, the type of enzymes involved in the element transfers, as well as varied physi- cal and chemical parameters (temperature, $\mathrm{pH}$, Eh, solution composition, ion complexation, soil porosity, microbial activities, etc.) of the soil-plant root environments.

Here, the collected plants have REE distribution patterns relative to their substrate that are characterized by: 1) a more pronounced enrichment in the LREEs than in the heavy REEs (HREEs), 2) a slightly negative Ce anomaly, and 3) a significant positive Eu anomaly. Such fractionations were attributed to variations in the stability constants of complexation processes involving an interaction of the REEs with different ligands. The literature abounds with studies on REE fractionation due to bindings to different common ligands such as carbonates, sulphates, phosphates, acetates, oxalates, etc. The readers may be referred to the works of Evans [36], Cantrell and Byrne [37], Millero [38], Tao et al. [39], among many others. The enrichment in LREEs in the plants studied here can be explained as resulting from high concentrations of low-molecular organic ligands, such as citrates, malates and oxalates, in the rhizosphere solutions [40-42], whereas the enrichment in HREEs could result from their complexation with intrinsic chelators in the xylem.

R. sativus collected from substrates polluted with 1000 and $4000 \mathrm{mg} / \mathrm{L}$ of $\mathrm{AgNO}_{3}$ was depleted in its overall contents in REEs relative to that grown in the unpolluted substrate. The REE transfer to the plants collected from substrate polluted with the intermediate Ag concentration of $2000 \mathrm{mg} / \mathrm{L}$, that is to say to the plants that accommodated the highest absolute Ag concentrations measured in the plants (Table 1), did not change, except for Sm that was found enriched in the plants. $R$. raphanistrum from substrate polluted by $2000 \mathrm{mg} / \mathrm{L} \mathrm{AgNO}_{3}$ yield the highest REE content relative to that in the substrate. The distribution pattern of REEs remained almost identical in these plants relative to that of the plants grown in the variably polluted substrates. The $R$. raphanistrum species takes up more REEs from substrate at a given $\mathrm{Ag}$ concentration probably due to a higher production of ligands.

All plants have a positive $\mathrm{Eu}$ anomaly relative to the REE distribution in the substrate, except for $R$. raphanistrum grown in the unpolluted substrate. This anomaly can reflect the Eu oxidation from a $\mathrm{II}^{(+)}$state to a $\mathrm{III}^{(+)}$ state in the rhizosphere and its complexation. In both cases, the Eu anomaly increases in the plants grown in polluted substrates relative to those grown in the unpolluted substrate. It varies as follows: lowest in the plants from the substrate polluted by $1000 \mathrm{mg} / \mathrm{L} \mathrm{AgNO}_{3}$, higher in plants from the substrate polluted by $4000 \mathrm{mg} / \mathrm{L}$ $\mathrm{AgNO}_{3}$, and highest in the plants from the substrate polluted by $2000 \mathrm{mg} / \mathrm{L}$. Compared to the other REEs, the preferential transfer of Eu from substrates to both species of plants appears to be the highest at a substrate pollution level of $2000 \mathrm{mg} / \mathrm{L}$, confirming that $\mathrm{Ag}$ addition to soils may not be necessarily toxic or even lethal to plants. 
In a soil environment, the Eu anomaly is commonly explained in terms of changes in the oxidation-reduction conditions, since Eu can occur in natural mineral environments in both the $\mathrm{Eu}^{(\mathrm{II})}$ and $\mathrm{Eu}^{\text {(III) }}$ oxidation states. Based on this reasoning, the positive Eu anomaly observed here for the plants implies reduction conditions in the substrate environment favoring incorporation of $\mathrm{Eu}$ in the $\mathrm{Eu}^{(\mathrm{II})}$ oxidation state. Since the roots of the plants were shallowly buried, only within 2 - 3 centimeters below the substrate surface, and the substrate on which the seeds were spread was only loosely packed, it is difficult to assert modifications in the oxidation/reduction conditions in the substrate during the period of plant growth. Also, since both species of radish had the same anomaly in Eu (about 1.6) relative to the substrate, which was lower at a pollution level of 1000 and $2000 \mathrm{mg} / \mathrm{L}$ of $\mathrm{AgNO}_{3}$, the anomaly may reflect the high availability of $\mathrm{Eu}$ in the substrate compared to the other REEs as well as its mobility from rhizosphere to the roots through preferential active sites on enzymes, which could have been modified by the abnormal concentrations of Ag.

The mechanisms by which Eu is enriched could record a modification in the enzyme activity in conjunction with a modification in the microorganic populations. These populations could have been altered by the addition of $\mathrm{Ag}$ to the substrate consequently inducing modifications in the oxidation-reduction conditions of the root environment. Such a hypothesis is supported by a previous study showing a Gd fractionation relative to the other REEs reported by Semhi et al. [35] for the two same radish species grown in different unpolluted clay substrates. Depending on the active sites of the occurring enzymes in the rhizosphere, the appropriate enzymes could have preferentially favored the uptake of one or possibly several REEs, and the Ag pollution of the substrate could have modified the enzyme or microorganic activity.

The increase in the REE contents of both species from polluted substrates relative to the same species from unpolluted substrate may result from a progressive increase in the amount of microorganisms and ligands involved in the complexation of the REEs that facilitate their transfer from rhizosphere to the plants. In fact, the fractionation of the REEs did not change significantly when the amount of Ag added to the substrates increased. Only the total amount of REEs transferred to the plants and the degree of the Eu anomaly changed. This could mean that the amount of polluting Ag was not determining for the uptake of REEs, as long as the amount of $\mathrm{Ag}$ in the substrate was significant. The mobility of REEs in the plants may not have changed, and this may be due to the resistance of some microorganism populations to the increasing $\mathrm{Ag}$ contamination. In this case, the enrichment in LREEs in both species could result from high concentrations of low-molecular organic ligands, the production of which being induced by the presence of $\mathrm{Ag}$ in the clay substrate.

\section{Conclusions}

Variable additions of $\mathrm{AgNO}_{3}$ as a pollutant to a substrate consisting of a smectite clay mineral that is interlayer expandable and cation exchangeable had varied impacts on the chemical composition of two species of radish grown during a laboratory experiment. The highest $\mathrm{Ag}$ uptake was by the cultivated Raphanus sativus, the highest "contamination" in the plant occurred at the addition of $2000 \mathrm{mg} / \mathrm{L} \mathrm{AgNO}_{3}$ to the substrate and, surprisingly, the lowest plant contamination occurred at an addition of the highest $\mathrm{AgNO}_{3}$ pollution at $4000 \mathrm{mg} / \mathrm{L}$. The $\mathrm{Ag}$ uptake by the wild Raphanus raphanistrum correlates positively with the increased addition of $\mathrm{Ag}$, from 1000 to $4000 \mathrm{mg} / \mathrm{L} \mathrm{AgNO}_{3}$, to the substrate. The pollution of the substrate by $\mathrm{AgNO}_{3}$ decreased the accumulation of most major and trace elements in the cultivated Raphanus sativus, while it increased their accumulation in the wild Raphanus raphanistrum.

The transfer of REEs from clay substrate to the two species of radish was increased by the addition of $\mathrm{AgNO}_{3}$ as a pollutant, whatever the amount. The highest uptake of REEs occurs at an intermediate addition of $\mathrm{AgNO}_{3}$ $(2000 \mathrm{mg} / \mathrm{L})$. The observed positive Eu anomaly in the REE patterns of the plants could have resulted from site activity of the enzymes or from microorganisms in the rhizosphere; it cannot be related to changing oxidationreduction conditions in the substrate during plant growth. The pollution of the substrate by $\mathrm{AgNO}_{3}$ did not induce a significant fractionation of the REEs in both radish species, when compared to the REE spectra of the species grown in the unpolluted substrate.

The experiment showed also that the use of a monomineralic substrate has the advantage to relate strictly the elemental variations in the plants to the microbiological activity after seeding, as almost none existed in the substrate before and to the enzymatic activity in the plant. It also allows discarding external parameters such as the physical and chemical properties of the soil and the climatic changes. Also, because of the abnormally high occurrence of $\mathrm{AgNO}_{3}$ in the substrate, changes in the elemental complexation and modification of enzyme activity could have occurred, potentially explaining the selective uptake of some elements and the changes in the element mobility in the two species of radish.

\section{Acknowledgements}

The authors are very grateful to Professor Mary Beth Kirkham (KSU, USA) for her detailed reading and improvement of the script before submission. We would also like to thank the two anonymous reviewers for the 
constructive comments and the editor of GSC for help during the publication round, as well as Hugh Rollinson and Tabisam Khan from the College of Sciences (SQU, Oman) for providing access to their laboratory for sample preparation.

\section{REFERENCES}

[1] T. W. Purcell and J. J. Peters, "Sources of Silver in the Environment: Silver Toxicity," Environmental Toxicology and Chemistry, Vol. 17, No. 4, 1998, pp. 539-546.

[2] K. E. Giller, E. Witter and S. P. McGrath, "Toxicity of Heavy Metals to Microorganisms and Microbial Processes in Agricultural Soils: A Review," Soil Biology and Biochemistry, Vol. 30, No. 10-11, 1998, pp. 1389-1414. doi:10.1016/S0038-0717(97)00270-8

[3] S. S. Sengor, S. Barua, P. Gikas, T. R. Ginn, B. Peyton, R. K. Sani and N. Spycher, "Influence of Heavy Metals on Microbial Growth Kinetics Including Lag Time: Mathematical Modelling and Experimental Verification," Environmental Toxicology and Chemistry, Vol. 28, No. 10, 2009, pp. 2020-2029. doi:10.1897/08-273.1

[4] M. Seif Sahandi, A. H. Sorooshzadeh, S. Rezazadeh and H. A. Naghdibadi, "Effect of Nano Silver and Silver Nitrate on Seed Yield of Borage," Journal of Medicinal Plants Research, Vol. 5, No. 2, 2011, pp. 171-175.

[5] S. Silver and T. K. Misra, "Plasmid-Mediated Heavy Metal Resistances," Annual Review in Microbiology, Vol. 42, 1988, pp. 717-743. doi:10.1146/annurev.mi.42.100188.003441

[6] G. Tyler, P. A. M. Balsberg, G. Bengtsson, E. Baath and L. Tranvik, "Heavy-Metal Ecology of Terrestrial Plants, Microorganisms and Invertabrates," Water, Air and Soil Pollution, Vol. 47, No. 3-4, 1989, pp. 189-215. doi:10.1007/BF00279327

[7] C. Barnhart and J. R. Vestal, "Effects of Environmental Toxicants on Metabolic Activity of Natural Microbial Communities," Applied Environmental Microbiology, Vol. 46, No. 5, 1983, pp. 970-977.

[8] W. A. Said and D. L. Lewis, "Quantitative Assessment of the Effects of Metals on Microbial Degradation of Organic Chemicals," Applied Environmental Microbiology, Vol. 57, No. 5, 1991, pp. 1498-1503.

[9] R.-A. Sandaa, Ø. Enger and V. L. Torsvik, "Abundance and Diversity of Archaea in Heavy-Metal-Contaminated Soils," Applied Environmental Microbiology, Vol. 65, No. 8, 1999, pp. 3293-3297.

[10] S. I. Kolesnikov, K. S. Kazeev and V. F. Val'kov, "The Effect of Heavy Metal Contamination on the Microbial System in Chernozem," Eurasian Soil Science, Vol. 32, No. 4, 1999, pp. 459-465.

[11] H. N. P. John and R. S Tripathi, "Decomposition of Fine Roots of Pinus Kesiya and Turnover of Organic Matter, N and $\mathrm{P}$ of Course and Fine Pine Roots and Herbaceous Roots and Rhizomes in Subtropical Pine Forest Stands of Different Ages," Biology Fertilizers and Soils, Vol. 35, No. 4, 2002, pp. 238-246. doi: $10.1007 / \mathrm{s} 00374-002-0470-8$
[12] F. Gremion, A. Chatzinotas, K. Kaufmann, W. Von Sigler and H. Harms, "Impacts of Heavy Metal Contamination and Phytoremediation on a Microbial Community during a Twelve-Month Microcosm Experiment," FEMS Microbiology Ecology, Vol. 48, No. 2, 2004, pp. 273-283. doi:10.1016/i.femsec.2004.02.004

[13] C. Reimann and P. De Caritat, "Chemical Elements in the Environment. Facts Heets for the Geochemist and Environmental Scientist," Springer Verlag, Heidelberg, 1998.

[14] H. T. Ratte, "Bioaccumulation and Toxicity of Silver Compounds: A Review," Environmental Toxicology and Chemistry, Vol. 18, No. 1, 1999, pp. 89-108. doi:10.1002/etc.5620180112

[15] B. Isikili, T. A. Demir, Ü. Özelmas and A. Berber, "Effects of Silver on Humans Living Near a Silver Mine," Journal of Medical Science, Vol. 28, No. 6, 1998, pp. 655-659.

[16] M. C. Jung, "Heavy Metal Contamination of Soils and Waters in and around the Imcheon Au-Ag Mine, Korea," Applied Geochemistry, Vol. 16, No. 11-12, 2001, pp. 1369-1375. doi:10.1016/S0883-2927(01)00040-3

[17] C. G. Lee, H.-T. Chon and M. C. Jung, "Heavy Metal Contamination in the Vicinity of the Daduk Au-Ag-Pb- $\mathrm{Zn}$ Mine in Korea," Applied Geochemistry, Vol. 16, No. 1112, 2001, pp. 1377-1386. doi:10.1016/S0883-2927(01)00038-5

[18] D. Cicchella, B. De Vivo, A. Lima, S. Albanese, R. A. R. McGill and R. R. Parrish, "Heavy Metal Pollution and Pb Isotopes in Urban Soils of Napoli, Italy," Geochemistry: Exploration, Environment, Analysis, Vol. 8, No. 1, 2008, pp. 103-112. doi:10.1144/1467-7873/07-148

[19] A. H. Cornfield, "Effects of Addition of 12 Metals on Carbon Dioxide Release during Incubation of an Acid Sandy Soil," Geoderma, Vol. 19, No. 3, 1977, pp. 199203. doi:10.1016/0016-7061(77)90027-1

[20] T. Murata, M. Kanao-Koshikawa and T. Takamatsu, "Effects of $\mathrm{Pb}, \mathrm{Cu}, \mathrm{Sb}$, In and Ag Contamination on the Proliferation of Soil Bacterial Colonies, Soil Dehydrogenase Activity, and Phospholipid Fatty Acid Profiles of Soil Microbial Communities," Water, Air and Soil Pollution, Vol. 164, No. 1-4, 2005, pp. 103-118. doi:10.1007/s11270-005-2254-X

[21] T. Pümpel and F. Schinner, "Silver Tolerance and Silver Accumulation of Microorganisms from Oil Materials of a Silver Mine," Applied Microbiology and Biotechnology, Vol. 24, No. 3, 1986, pp. 244-247.

[22] M. Johansson, M. Pell and J. Stenstrom, "Kinetics of Substrate-Induced Respiration (Sir) and Denitrification: Applications to a Soil Amended with Silver," A Journal of the Human Environment, Vol. 27, No. 1, 1998, pp. 4044.

[23] R. R. Brooks, M. F. Chambers, L. J. Nicks and B. H. Robinson, "Phytomining," Trends in Plant Sciences, Vol. 3, No. 9, 1998, pp. 359-362. doi:10.1016/S1360-1385(98)01283-7

[24] T. Andrew, A. E. Harris and R. Bali, "On the Formation and Extent of Uptake of Silver Nanoparticles by Live Plants," Journal of Nanoparticle Research, Vol. 10, No. 4, 
2008, pp. 691-695. doi:10.1007/s11051-007-9288-5

[25] K. Semhi, N. Clauer and S. Chaudhuri, "Variable Element Transfers from an Illite-Rich Substrate to a Growing Plant during a Three-Month Experiment," Applied Clay Science, Vol. 57, 2012, pp. 17-24. doi:10.1016/j.clay.2011.12.002

[26] M. D. Moore and R. C. Reynolds Jr., "X-Ray Diffraction and the Identification and Analysis of Clay Minerals," 2nd Edition, Oxford University Press, Oxford, 1997.

[27] G. S. Odin and 35 Collaborators, "Interlaboratory Standards for Dating Purposes," In: G. S. Odin, Ed., Numerical Dating in Stratigraphy, Part 1, John Wiley \& Sons, Chichester, 1982, pp. 123-148.

[28] K. Govindaraju, "1994 Compilation of Working Values and Sample Description for 383 Geostandards," Geostandards Newsletter, Vol. 18, No. 1, 1994, pp. 1-158.

[29] C. Y. Chiu, M. K. Wang, M. C. Chen and H. B. King, "Physical and Chemical Properties in Rhizosphere and Bulk Soils of Tsuga and Yushania in a Temperate Rain Forest," Community Soil Science \& Plant Analysis, Vol. 33, No. 11-12, 2002, pp. 1723-1735. doi: $10.1081 /$ CSS-120004818

[30] J. F. Ma, "Plant Root Responses to Three Abundant Soil Minerals: Silicon, Aluminum and Iron," Critical Reviews in Plants, Vol. 24, No. 4, 2005, pp. 267-281. doi: $10.1080 / 07352680500196017$

[31] S. Clemens, D. M. Antosiewicz, J. M. Ward, D. P. Schartman and J. I. Schroeder, "The Plant cDNA LCT1 Mediates the Uptake of Calcium and Cadmium in Yeast," Plant Biology, Vol. 95, No. 20, 1998, pp. 12043-12048.

[32] V. K. Harold and L. B. Karen, "Silver Uptake, Distribution, and Effect on Calcium, Phosphorus, and Sulfur Uptake," Plant Physiology, Vol. 65, No. 2, 1980, pp. 336339. doi: $10.1104 /$ pp.65.2.336

[33] P. P. Motavalli, R. J. Kremer, M. Fang and N. E. Means, "Impact of Genetically Modified Crops and Their Management on Soil Microbially Mediated Plant Nutrient Transformations," Journal on Environmental Quality, Vol. 33, No. 3, 2004, pp. 816-824. doi: $10.2134 /$ jeq2004.0816
[34] W. W. Barker, S. A Welch, S. Chu and J. F. Banfield, "Experimental Observations of the Effects of Bacteria on Aluminosilicate Weathering," American Mineralogist, Vol. 83, No. 11-12, 1998, pp. 1551-1563.

[35] K. Semhi, S. Chaudhuri and N. Clauer, "Fractionation of Rare-Earth Elements in Plants during an Experimental Growth in Varied Clay Substrates," Applied Geochemistry, Vol. 24, No. 3, 2009, pp. 447-453. doi:10.1016/j.apgeochem.2008.12.029

[36] C. H. Evans, "Biochemistry of the Lanthanides," Plenum Press, New York, 1990.

[37] K. J. Cantrell and R. H. Byrne, "Rare Earth Element Complexation by Carbonate and Oxalate Ions," Geochimica et Cosmochimica Acta, Vol. 51, No. 3, 1987, pp. 597-605. doi:10.1016/0016-7037(87)90072-X

[38] F. J. Millero, "Stability Constants for the Formation of Rare Earth Element Complexes as a Function of Ionic Strength," Geochimica et Cosmochimica Acta, Vol. 56, No. 8, 1992, pp. 3123-3132. doi:10.1016/0016-7037(92)90293-R

[39] L. Tao, D. Shiming, Z. Chaosheny, Z. Zili, Y. Juncai and L. Haitao, "Fractionation of Rare Earth Elements in Plant. I. Fractionation Patterns and Their Forming Mechanisms in Different Organs of Triticium aestivum," Journal of Rare Earths, Vol. 23, 2005, pp. 224- 229.

[40] A. Wyttenbach, V. Furrer, P. Schleppi and L. Tobler, "Rare Earth Elements in Soil and in Soil-Grown Plants," Plant and Soil, Vol. 199, No. 2, 1998, pp. 267-273. doi:10.1023/A:1004331826160

[41] F. F. Fu, T. Akage and K. Shinotsuka, "Distribution Patterns of Rare Earth Elements in Fern: Implication for Intake of Fresh Silicate Particles by Plants," Biological Trace Element Research, Vol. 64, No. 1-3, 1998, pp. 13-26. doi:10.1007/BF02783321

[42] Z. G. Wei, M. Yin and X. Zhang, "Rare Earth Elements in Naturally Grown Fern Dicranopteris linearis in Relation to Their Variation in South-Jiangxi Region (Southern China)," Environmental Pollution, Vol. 114, No. 3, 2001, pp. 345-355. doi:10.1016/S0269-7491(00)00240-2 